\title{
RETHINKING THE CONTEMPORARY HISTORY OF FERTILITY: FAMILY, STATE, AND THE WORLD SYSTEM
}

\author{
MIKHAIL KLUPT
}

\begin{abstract}
The paper highlights the drivers of contemporary fertility history in developed countries "forgotten" by theory: fundamental changes in the world system after the Second World War and in the late 1980s and early 1990s; competing ideas of the "right" family and family and demographic policy; centre-peripheral relations and their impact on the resource capabilities of such policy. Statistical analysis shows that the periods during which countries' positions by total fertility rates remained stable were disrupted by intervals in which significant changes in these positions occurred. Twice, due to the Second World War and the disintegration of the Soviet bloc, such intervals coincided with fundamental shifts in the world system. In addition, such intervals occurred in Western countries in the late 1980s and early 1990s, when the negative association between women's participation in the labour force and fertility became positive, and then in the 2000s in Russia, countries of Eastern and Central Europe and the former Yugoslavia during fertility "recovery". Contemporary fertility changes in the developed world are directed by "gravitational fields" of four attractors. Three of them are institutional traps created by low living standards, or contradictions between the "new" economy and "old" family relations, or, in varying proportions, both. The fourth attractor is an ideal condition in which generous family policy and men's participation in the home maintain fertility at the replacement level. Currently, France and the Scandinavian countries come closest to this. The question of whether the developed semi-peripheral countries will be able to approach this condition, or, due to resource constraints, it will remain a privilege accessible only to the core countries, remains open.
\end{abstract}

Key words: fertility, demographic policy, family policy, centre-peripheral relations, world system.

Different, sometimes diametrically opposed interpretations of events are a characteristic feature of historical science. In contrast, interpretations of the modern history ${ }^{1}$ of fertility are not so variable - all of them, according to D. Van de Kaa (Van de Kaa 1996), are "anchored" to the theory of demographic transition. The purpose of this article is to present a different interpretation of changes in fertility, partly as an alternative to these theories, and partly as an addition to them.

The main "engine" and "intrigue" of the modern history of fertility in our interpretation will be the state's desire to reconcile the economic and demographic functions of the family. Policy aimed at achieving this goal has been based, as we show below, on competing ideas about what the relationship between the family and the state should be. These ideas and the results of their implementation have been largely determined by the course of political history and its most important element - center-peripheral relations in the world-system, and if one views the course of events even more broadly, by the fragmentation of the world, including the developed world, into qualitatively different and often conflicting parts.

Mikhail KluPt (klupt.m@unecon.ru), St. Petersburg State University of Economics (UNECON), Russia.

THE ORIGINAL ARTICLE IN RUSSIAN WAS PUBLISHED IN DEMOGRAPHIC REVIEW 2018, 5(3), 6-24.

DOI: 10.17323/DEMREVIEW.V5I3.8133

\footnotetext{
${ }^{1}$ Modern history in this article means the period from the end of the Second World War to the present day.
} 


\section{INERTIAL DEVELOPMENT AND BREAKS IN GRADUALITY: STATISTICAL ANALYSIS}

The periodization of history is one of the canonical approaches to its study. In our case, we construct such a periodization, dividing the historical flow into two types of periods: stable development and breaks in graduality. First, we will carry out such a division by the methods of statistical (mainly correlation) analysis, and then we will interpret the results obtained by placing them in a wider historical context.

Our statistical analysis covers two sets of countries from the developed world. The first consists of 22 countries that throughout the postwar period were either part of the US-led militarypolitical bloc, or, while being formally neutral (such as Austria and Sweden), indisputably belonged nevertheless to the western cultural $\mathrm{area}^{2}$. The second set (19 countries) includes Russia, European countries that were previously part of the USSR or the Soviet military-political bloc, as well as the states that previously constituted Yugoslavia ${ }^{3}$. The total of the two sets is 41 countries.

The first set of countries includes only countries of the core and semi-periphery of the developed world. The second set, before the collapse of the USSR and its geopolitical bloc, was a relatively isolated part of the world-system. In the 1990s and at the beginning of the 21st century, some of these countries joined the periphery, and some the semi-periphery of the developed world ${ }^{4}$. The time horizon of the analysis covers the period from 1950 to 2016. The initial data used were on the period total fertility rates (hereinafter referred to as the TFR), published in the electronic publication Demoscope Weekly (Demoscope Weekly. Supplementary materials 2018).

Breaks in graduality in the historical dynamics of fertility occur when the countries' ranks by fertility within the set of these countries are subject to significant changes. Because of this, an analysis of the diagonal matrix of correlation coefficients between the TFRs in the populations of the countries here considered allows us to reveal the place of the breaks of graduality on the historical axis ${ }^{5}$. In other words, the matrices of correlation coefficients obtained by the method described above show how strongly the distribution of countries according to leaders, "average performers" and "underperformers" of fertility for a given year is determined by their previous history. High values of the correlation coefficients indicate that the order in which the countries

\footnotetext{
${ }^{2}$ Australia, Austria, Belgium, UK, Germany, Greece, Denmark, Spain, Italy, Canada, Netherlands, New Zealand, Norway, Portugal, USA, Finland, France, Sweden, Switzerland, South Korea, Japan. Due to the lack of necessary information on the GDR in the database we used during the correlation analysis, we used a time series of total fertility rates from 1950 to 2016 for Germany as a whole.

${ }^{3}$ Belarus, Bulgaria, Bosnia and Herzegovina, Hungary, Lithuania, Latvia, Macedonia, Moldova, Poland, Russia, Romania, Serbia, Slovakia, Slovenia, Ukraine, Montenegro, Czech Republic, Croatia, Estonia.

${ }^{4}$ As can be seen from the above, we use some concepts of I. Wallerstein's world-system theory, but we do not strive to copy its classification of states. In our opinion, in the developed world it is also possible to distinguish its core, semi-periphery and periphery. Per capita income in the peripheral countries of the developed world is much lower than in its core and semi-periphery, but at the same time significantly exceeds the values of this indicator in the world's least developed (according to the UN classification) states. No less important is the fact that negative population growth rates are characteristic of the periphery of the developed world.

${ }^{5}$ The initial data for the calculations were a matrix of values of the TFR, the rows of which were countries, and the columns - years. The correlation coefficients between the columns of such a matrix were calculated. The result of the calculations is a matrix, the elements of which are the values of the correlation coefficients $r\left(T F R_{t}, T F R_{t-k}\right)$ between the TFR in the year $t$ and the year $t-k$, which is $k$ years ago from the year $t$. The correlation coefficients in such a matrix are measures of proximity between years, and not between countries.
} 
are lined up is not very variable, and low values indicate a significant change. The statistical significance of the correlation coefficients (if it occurs) allows us to reject the null hypothesis that the similarity in the position of countries in the years under consideration is random.

The results of the analysis indicate that the position of countries by the size of the TFR showed, as a rule, a strong dependence on previous development (Figure 1). From 1950 to 1980, in both sets, the correlation coefficients between the TFR of the current year and the TFR observed a decade earlier significantly exceeded their critical values. The dependence of fertility rates on previous development during this period is explained, in our opinion, by a combination of three factors: the stability of formal and informal institutions closely related to fertility, the stability of circumstances external to them and the absence (with some exceptions) of a demographic policy aimed at radically changing both. The "perturbations" that emerged at the end of this period (the demographic policy of Hungary, the GDR and Czechoslovakia, the ban on abortions in Romania, the fall of the Spanish and Portuguese dictatorships and the decline in fertility that followed) were not strong enough to shake this stability.

At the same time, periods of inertial development, during which the position of countries in terms of the total fertility rate changed very slowly, were interrupted several times by "breaks in graduality", which led to a significant change in this arrangement. At the same time, the set of 22 countries as a whole was more stable than the set of 19 countries.

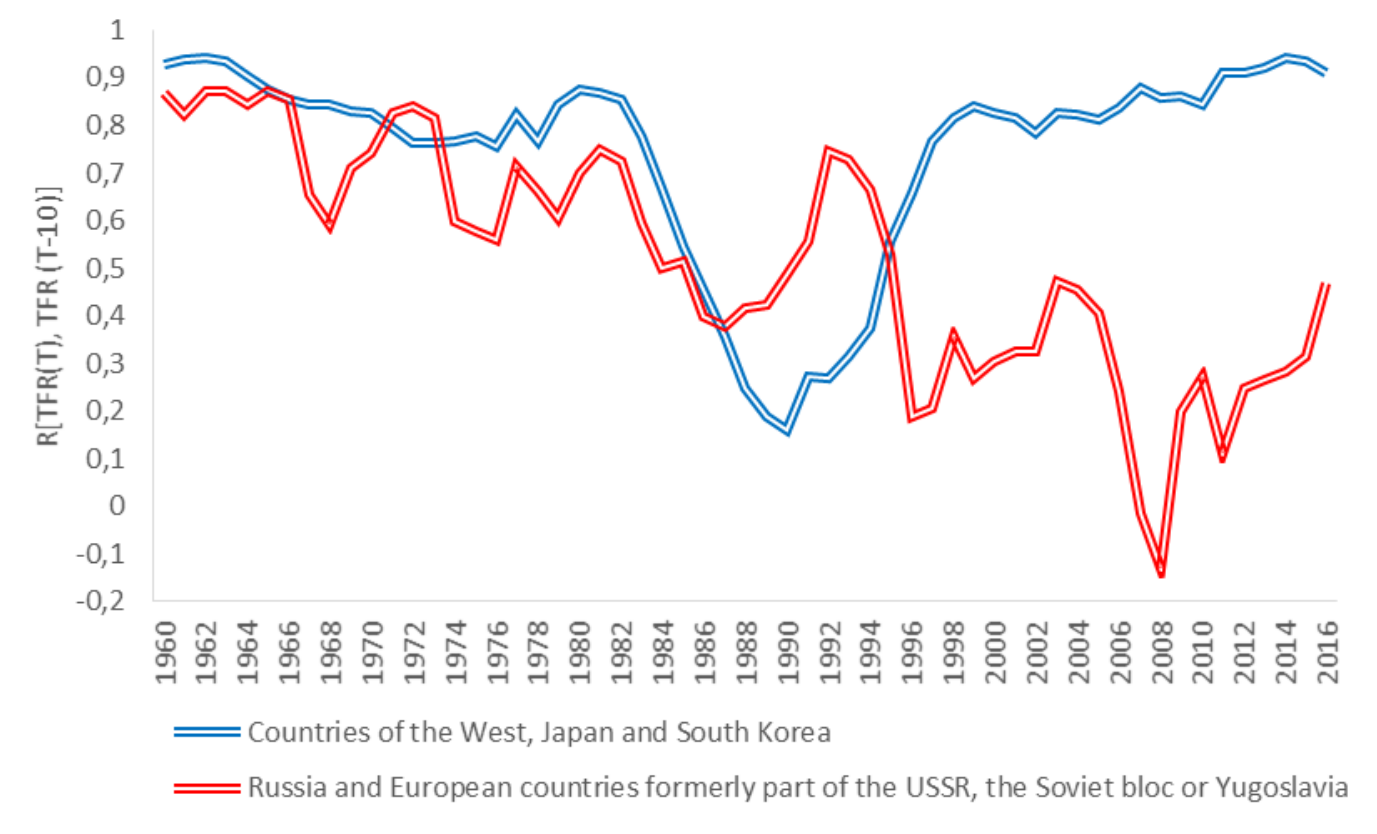

Figure 1. Correlation coefficients $r[\operatorname{TFR}(t), \operatorname{TFR}(t-10)]$ between the value of the total fertility rates in years $t$ and $(t-10)$

Source: Author's calculations based on (Demoscope Weekly. Supplementary materials 2018).

In the set of 22 countries, the period of the weakest dependence on previous development falls on 1987-1994, when the correlation coefficients between the TFR observed in the current year and a decade earlier fell below the critical 5\% significance level (0.42). In all other years, the correlation coefficients calculated in a similar way were statistically significant at the $5 \%$ level. 
The average TFR for the 22 countries considered in 2015 remained almost the same as in 2000 (1.62 and 1.61 respectively). Their ranks by this indicator almost did not change: the correlation coefficient between the values of the TFR in 2000 and 2015 was 0.83 .

In the set of 19 countries, the correlation coefficients between the TFR observed in the current year and a decade earlier fell below the critical 5\% significance level (0.46) three times: in 1986-1989, 1996-2002 and 2006-2015. The most pronounced breaks in graduality were those associated first with a sharp decline in TFR during the transformational shock, and then during their "restorative" growth, especially rapid in Russia".

For the two sets together (41 countries), the differences between the periods when the dependence on previous development was strong and the periods when it was disturbed are clearly seen in Figure 2. The statistically significant dependence on the TFR observed in 1950 remained not only in 1965, but also in 1980 ( $r=0.61$ and $r=0.51$, respectively). In contrast, the dependence of the TFR on their values recorded in 1980 and 1990 disappeared much faster and in 10-12 years ceased to be statistically significant.

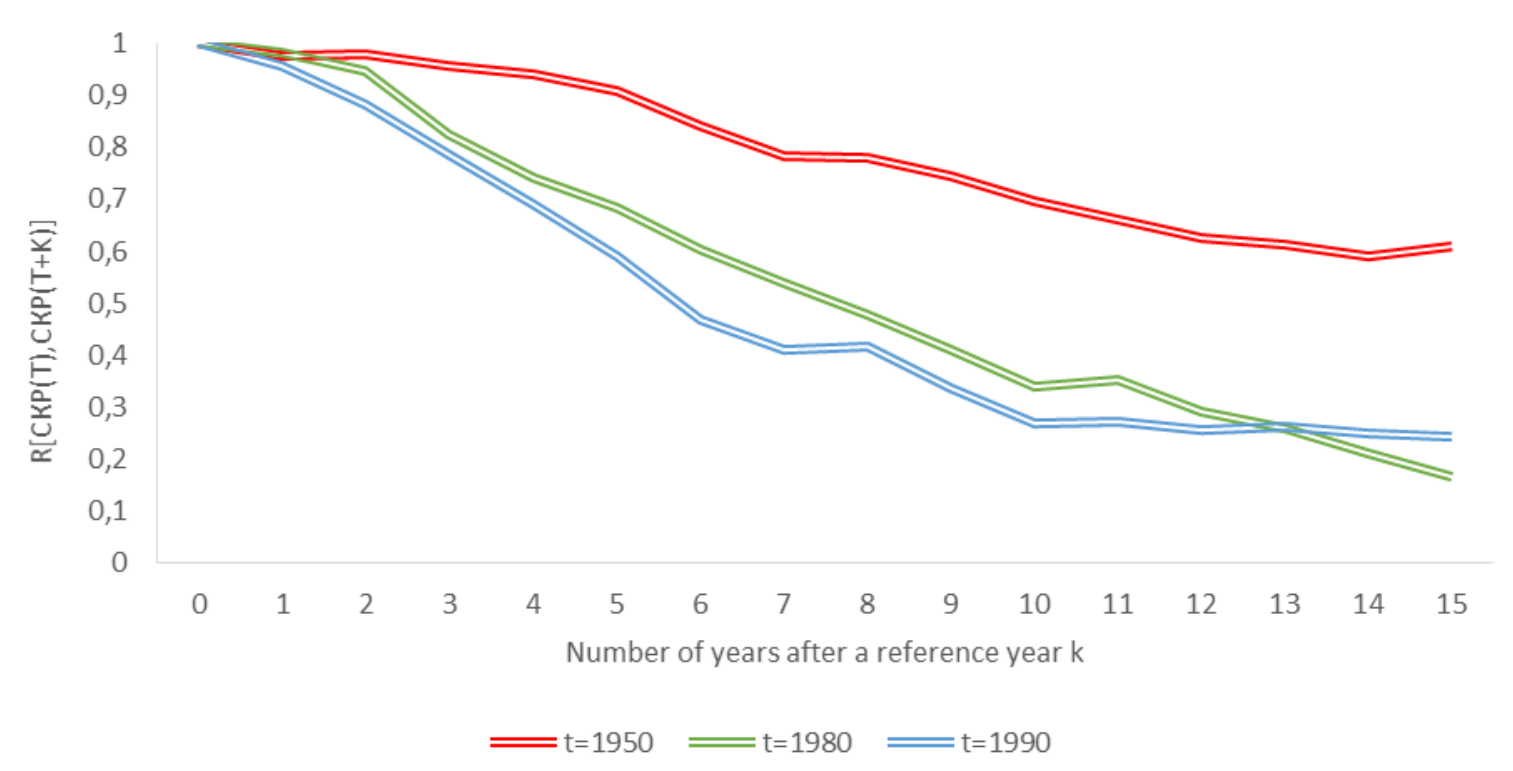

Figure 2. Correlation coefficients $r[\operatorname{TFR}(t), \operatorname{TFR}(t+k)]$ between the value of the total fertility rates in the year $t$ and the year that is $k$ years ahead of it, for 41 developed countries

Source: Author's calculations based on (Demoscope Weekly. Supplementary materials 2018).

Dependence on previous development is also observed when the average total number of births in the cohorts per woman is used as an indicator of fertility. Thus, for 23 OECD countries, the correlation coefficients between the average number of births per woman in the corresponding cohorts were: for the cohorts of those born in 1950 and 1960, 0.816; for those born in 1960 and

${ }^{6}$ From 2000 to 2015, the average TFR in this set of countries (excluding data for Russia) increased from 1.36 to 1.51. In Russia, the value of the TFR grew much faster - from 1.20 to 1.78. At the same time, in the aforementioned set of 19 countries the dependence on the values of the TFR recorded in 2000 was, since 2007, no longer statistically significant. 
1970, 0.898; and for those born in 1950 and 1970, 0.623. All the given correlation coefficients are statistically significant at the level $\alpha=0.01^{7}$.

\section{THE POSTWAR BABY BOOM}

Let us now consider the above data in a broader context, including, along with political events and economic upheavals, the competition of ideas that underlie the demographic and family policy of the state. These ideas (which together we will also call family doctrine) can be divided into two large classes. The ideas relating to the first of them are based on the assumption that the family is capable of providing an acceptable level of generation replacement for society without any particularly generous state stimulation of fertility. Such a doctrine considers family assistance primarily as the fight against poverty and does not consider it necessary to pay special attention to material incentives for fertility. The second set of ideas, an alternative to the first, is that "just" family policy aimed at fighting poverty is not enough, and the demographic goals of society can be achieved only with active stimulation of fertility by the state. During the postwar baby boom, both ideas were expressed in political practice.

The dynamics of fertility in this period were to a large extent due to a complex of factors well described by the theory of the demographic transition. Another factor, to which less attention is usually paid, is the results of the Second World War. The mediating factor in the influence of these results was demographic policy, as a result of which France, which in the period between the two world wars had a lower fertility than Germany and Italy, in the postwar period overtook them both.

In the Western world, the ideological context of the baby boom included two opposing family doctrines. One of them dominated in France, the other in Germany, Italy and, in its extreme manifestations, in Francoist Spain. France continued its pre-war demographic policy, the characteristic features of which were officially declared pronatalism and generous assistance to families with children. General de Gaulle declared in a speech on March 2, 1945 that "the French population is not increasing, and France may turn into a dying great light. But even in this area, nothing is lost, if only we want to act. We need 12 million healthy babies to appear in the next ten years" (De Gaulle 2004: 502-503).

The defeat of fascism in the Second World War made pro-natalist demographic policy in the Federal Republic of Germany and Italy impossible, since in the Nazi ideology the promotion of the birth rate of "true Aryans" was inextricably linked with the genocide of other nations. The basis of the family doctrines of Italy and the Federal Republic of Germany were now religious and conservative principles. It was assumed that the "natural family", in which the father is the breadwinner and the mother takes care of the house and raises the children, is fully capable of providing an adequate level of fertility even without generous benefits like the French ones. The German labor minister believed, for example, that the size of French benefits discouraged

\footnotetext{
${ }^{7}$ Author's calculations based on (Family Database 2018: data for Chart SF 2.1.B). We also note that the predominant use in our analysis of period TFRs, rather than cohort indicators, is due to the fact that the latter are much more difficult to tie to certain political events, since each of the cohorts passed through many of them during their life course.
} 
the fathers of families from wanting to work (Niehus 1995: 311). If in France in 1957 the appearance of a third and subsequent children reduced (compared to a childless married couple) the family's standard of living by only $9 \%$, then in Germany this reduction was $36 \%$ for a third child, $39 \%$ for a fourth, $43 \%$ for a fifth and $46 \%$ for a sixth (Niehus 1995: 311).

The family doctrine of Spanish Francoism was an extreme manifestation of religiously conservative views of the family. The work of women outside the family was interpreted as a social evil that distracts a woman from her natural purpose - having and raising children. Prior to the transition of Francoism to a more liberal economic policy, labor laws legitimized discrimination against women in employment. It was only in 1961 that the statutes were abolished according to which women, regardless of their wishes, could be dismissed from work when they got married. Women were forbidden to occupy leadership positions, and married women were allowed to get a job or engage in commercial activities only with the consent of their spouse (Nielfa Cristóbal 2003; Morago Garcia 2008: 247).

\section{DEMOGRAPHIC POLICY AND FERTILITY IN THE $1970 S$ AND $1980 S$}

The USSR and the countries of the Soviet bloc. The stable distribution of countries by fertility, characteristic of the period of the post-war baby boom, began to break down already in the 1970s. This break in graduality was largely due to the dual fragmentation of the world in that era: on the one hand, into the West and the Soviet bloc opposing it, and on the other, into the core, semiperiphery and periphery of the West itself. The confrontation between the West and the Soviet bloc affected almost all spheres of public life at that time. The intensification of demographic policy in the USSR and the countries of the Soviet bloc was largely due to this confrontation.

T. Frejka wrote then in a journal, one not at all inclined to propagate the achievements of the Soviet bloc, that "young people in Czechoslovakia probably live in the context of the widest, most all-embracing and cost-intensive fertility policy in the world" (Frejka 1980: 89). As in France, such a policy was to a large extent a consequence of foreign policy factors. The population of the countries that formed at that time the "western outpost" of socialism inevitably compared their standard of living with the standard of living of their capitalist neighbors. To survive the constant competition with the geographically and culturally close West, the governments of Hungary, the German Democratic Republic and Czechoslovakia had to maintain fairly high living standards, and demographic policy was one of the methods for solving this problem. The ideological factor probably also played a certain role: the interpretation of low birth rates as evidence of the decline of the entire social system never completely disappeared from the politicaldemographic arena, and lingers on even now.

As a result of demographic policy measures taken in 1970-1973, the TFR in Czechoslovakia increased from 2.07 in 1970 to 2.46 in 1975, but then began to decline and by 1980 did not exceed the values of a decade before. The dynamics of the TFR in Hungary and the GDR were of a similar nature. Such dynamics are often interpreted as a textbook example of the ephemeral effect of demographic policy. However, if we consider the results of the demographic policy of these countries through the prism of the "competition of the two 
systems", which then affected all spheres of public life, the picture is different. The Czech Republic, which in 1970 occupied 39th place in terms of the TFR among the 41 countries listed above, by 1990 had risen to 16th place, while Slovakia moved from 16th to 7th place, and Hungary from 36 th to 20 th.

The demographic policy of the USSR in the 1980s was determined mainly by the same motives as in the above-mentioned countries of the Soviet bloc. In addition, in Russia, with its vast territory, the claim about the need for population growth has always (with the possible exception of the short period of the 1990s) been perceived by both those "above" and those "below" as something natural, and justified not least of all by the need to protect their territory from external invasions. The TFR in Russia increased during this period faster than in developed countries. If, in 1980, Russia ranked 28th in this indicator among the 41 countries mentioned above, in 1985 it was 13th. In the conditions of constant information wars and the "competition of the two systems", this circumstance, regardless of whether it was actually connected with the demographic policy of the state or not, was perceived as an undoubted achievement ${ }^{8}$.

The demographic policy of the USSR and the countries that were part of the Soviet bloc was thus quite adequate to the social system for which it was created, and to the political and ideological tasks that it solved. The sharp decline in fertility in the 1990s was no longer related to this policy and was caused by the transformation of all public, and indeed daily life.

Western countries. During the postwar baby boom, the influence of family doctrines on fertility in the countries of Western and Southern Europe seemed insignificant. However, since the 1970s, this influence has become increasingly apparent. The differences between the ranks of the 22 above-mentioned countries in terms of the TFR in 1975 and 1990 were striking: a statistical analysis suggests that both series are practically independent of each other $(r=0.02)$. A significant contribution to this difference was made by the rapid fertility decline in the countries of Southern Europe (Greece, Spain, Italy and Portugal), which (with the possible exception of Italy) were in that period in the semi-periphery of the developed world. The TFR in these countries decreased by $0.94,1.44,0.84$ and 1.19 points, respectively, with an average decline of 0.40 points in the population of the set of 22 countries considered. Spain, which occupied 3rd place in terms of the TFR among these countries in 1975, had moved to the penultimate 21 st place by 1990 , and Italy from 7 th to the last, or 22 nd.

The modern history of fertility in the countries of Southern Europe has both its own distinctive features and similarities. In Spain and Portugal, the rapid decline in fertility was closely associated with the transition from autarchy to close integration into the Western world and a constituent part of it - the European Union. In Spain, the process of careful rapprochement with the Western bloc was observed already in the 1960s; it can be assumed that the same process gradually created the prerequisites for the subsequent decline in fertility. However, the trigger for such a reduction was the death in 1975 of the Spanish dictator F. Franco and the subsequent adoption in 1978 of a new Constitution, which legalized gender equality (Figure 3).

\footnotetext{
${ }^{8}$ We note a parallel, not usually noticed by demographers and statisticians, between the period TFR and indicators of financial markets. Both of these, regardless of what they actually reflect and whether they are correctly interpreted, influence their users' behavior and, consequently, political and economic life.
} 


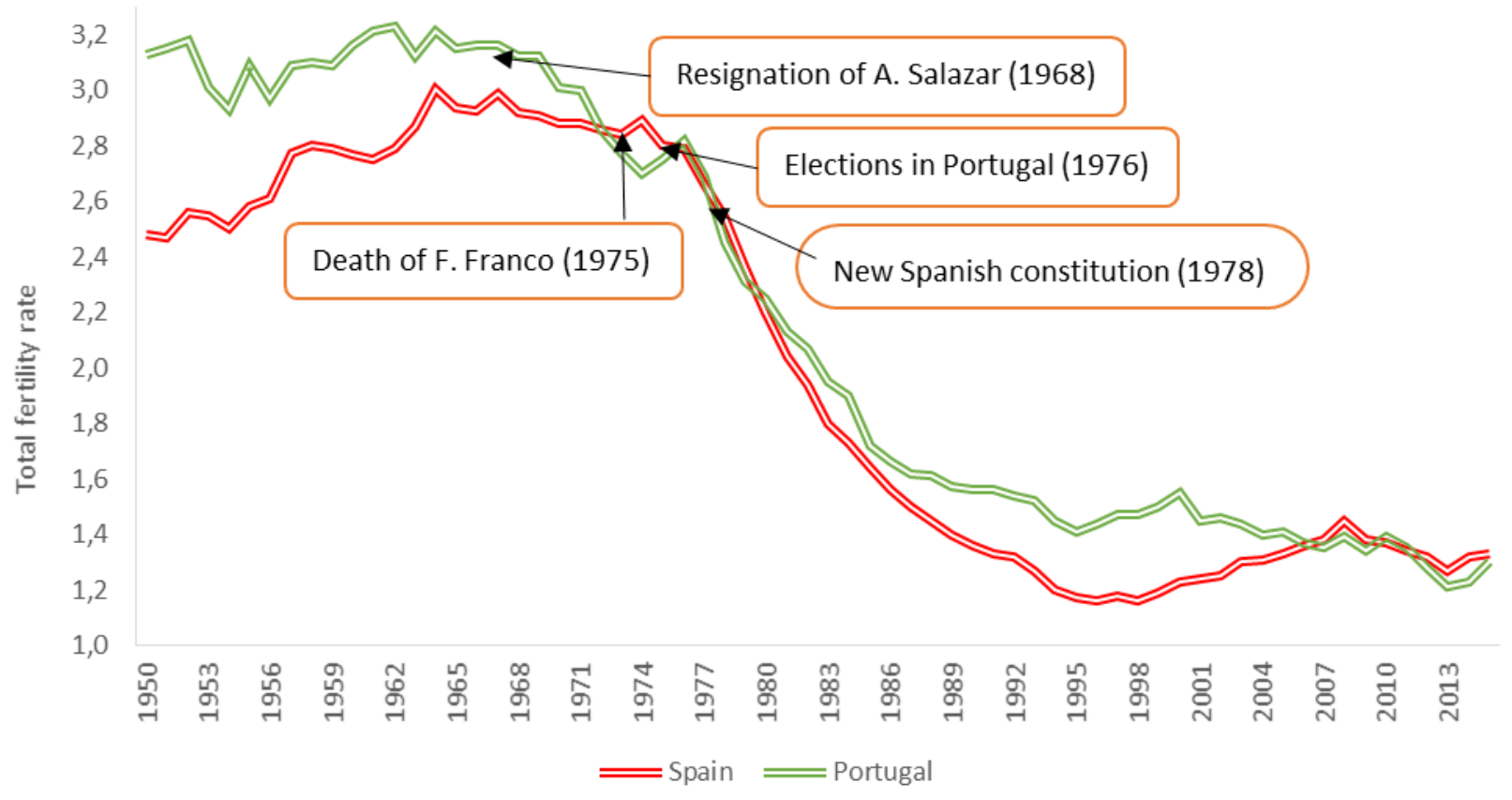

Figure 3. Total fertility rate in Spain and Portugal, 1950-2015

It should also be borne in mind that Spain's transition to a new form of government and the integration of this country into the European Union took place in an environment where the "old" family policy no longer existed, and the new one was significantly inferior to most Western European countries in terms of the scale of assistance provided to families. For example, in Spain in 2001, family spending was $0.1 \%$, while in France it was 2\% (Meil Landwerlin 1995: 75). In Portugal, events evolved according to a similar scenario: here, too, a rapid decline in fertility began shortly after the resignation of A. Salazar (1968), the overthrow of the dictatorship (1974) and the first free parliamentary elections of 1976 in half a century (Figure 3). In general, the rapid and deep decline in fertility in the countries of the Iberian Peninsula was, in our opinion, the "demographic price" of abandoning its isolated development and transitioning to the position of a semi-peripheral country in the Western world, and at the same time one of many illustrations of the fact that the family model with a breadwinner father and housewife mother can no longer provide for the simple replacement of generations.

In Italy, by contrast, the sharp decline in fertility was not associated with the radical change in the mode of political government that occurred in Spain and Portugal. Rather, it is a matter of certain significant political events testifying to the frame of mind in the country. Among them, of course, is the referendum of 1974, in which the majority (59.3\%) of Italians opposed the repeal of the recently adopted law liberalizing divorce, as well as the referendum of 1981, in which $88.4 \%$ of voters voted against repealing the law liberalizing abortion.

Statistical analysis carried out by P. Rindfuss and his co-authors (Rindfuss et al. 2003) for 22 OECD $^{9}$ countries showed that the inverse relationship between the employment rates of women

\footnotetext{
${ }^{9}$ In our analysis, unlike (Rindfuss et al. 2003), we excluded from this set of 22 countries Luxembourg and added to it the Republic of Korea. Otherwise the sets here considered are the same. URL: https://stats.oecd.org/Index.aspx?DataSetCode=LFS_SEXAGE_I_R\# (access date: 05/05/2018).
} 
and fertility observed in 1970 had changed to a direct one by 1990. In Sweden and Norway, which were characterized by very high levels of employment for women (in 1990, 81.0 and 67.2\% respectively of women aged 15-64), TFR (2.13 and 1.93 in the same year ) was in 1990 close to the replacement level, whereas in Spain and Italy, low levels of female employment (31.8 and $36.2 \%$, respectively) were accompanied by very low TFR values (1.36 and 1.33) (LFS ... 2018).

The fact that fertility in the Federal Republic of Germany was considerably lower throughout the postwar period than in France did not attract attention as long as fertility in both countries ensured simple replacement of the parental generation by the generation of children. However, by the mid-1970s the role of family doctrines became apparent: the German TFR (1.48) in 1975 was already significantly different from France's (1.93).

A significant contribution to the break in graduality in the period under review was also made by Japan and, especially, South Korea, which moved from 1st place in terms of TFR among these 22 countries in 1975 to 14th in 1990. Both countries, concerned after the end of the Second World War I by decreasing rather than increasing fertility, fell into an institutional trap: the contradiction between new economic realities and traditional family institutions led to the fact that women began marrying later and having fewer children.

Also contributing to this period's break in graduality was Sweden, where the so-called "speed premium" was introduced in 1986, making it economically beneficial for parents to reduce the interval between births (Andersson, Hoem, Duvander 2005). By 1990, the TFR in Sweden reached 2.13. If in 1975 Sweden shared 16th and 17th places in terms of TFR among the 22 named countries, in 1990 it was already in second place.

Summarizing the above, we note that the change that took place in the period under review in the positions of western bloc countries in terms of fertility had several causes. One of them was the fall of the Spanish and Portuguese dictatorships and the subsequent transition from isolation to integration into the semi-periphery of the capitalist world-system. The demographic price of this transition, which was not accompanied by the adoption of a new and fairly generous family policy, turned out to be a rapid and profound decline in fertility.

Another reason was that, on the European continent, the doctrine of a "natural" family with a breadwinner father and housewife mother, ideal from a religious and conservative point of view, suddenly turned out to be incompatible with maintaining an acceptable level of fertility. Such a course of events became a vivid example of the unintended consequences of politics: in Europe, by the end of the period under review, the countries where the ideal of a conservative family was put into practice by the state more consistently ended up lagging behind in terms of fertility. In countries that, like Sweden, have modernized their family policies so that they correspond to the new realities and support the combination of the parental and professional functions of women, fertility has been higher.

The history of fertility in the United States is different in this respect from that in Europe. Conservative white Americans, in families of which three or four children are not uncommon, make up a large part of the American population. In (Lesthaeghe, Neidert 2009), based on statistical analysis, it is shown that voting for the US Republican Party and rejecting the values underlying the second demographic transition are closely related. The victories of the Republicans 
in the presidential and congressional elections in 2016 are indirect evidence that the population of this group of the United States is still very significant.

\section{THE PAST QUARTER-CENTURY AND FUTURE PROSPECTS}

The collapse of the USSR and the Soviet bloc entailed both new and very significant changes in the positions of countries in terms of fertility. By 2000, this position was significantly different from 1990 - the rankings of countries formerly belonging to the USSR, the Soviet bloc or Yugoslavia dropped sharply. Payment for integration into the world-economy, as in the case of Spain and Portugal, was a sharp decline in fertility. The mediating factors, the relative importance of which remains controversial to this day, were a sharp decline in living standards, changes in the life plans of young people (the practical expression of which often became emigration to the countries of the world-system core), later birth of children, and the degradation of population policy. Russia, which ranked 18th in terms of TFR in 1990, dropped to 39th by 2000; Hungary fell from 20th to 27th place, Poland from 10th to 23rd, and the Czech Republic from 16th to 40th. In 2000, the differences between the average TFR values for countries that underwent socioeconomic transformation (1.35) and the other countries of the set considered (1.61) were statistically significant by the $t$-test at $\alpha<0.001$.

The political and economic restructuring of the world led to significant changes in the nature of the relationship between living standards and fertility in developed countries. If, in 1950, in countries with developed market economies no relationship between per capita GDP (PPP) and TFR was observed $(r=0.07)$, then by 1990 it was already quite clearly indicated $(r=0.425$, significant at the level $\alpha=0.05)^{10}$. At the same time, it turned out that a high per capita income, while necessary, is an insufficient condition for a relatively high fertility (Table 1).

Table 1. Distribution of 22 countries with developed market economies by the total fertility rate in 1990

\begin{tabular}{l|c|c|c|c}
\hline \multirow{2}{*}{$\begin{array}{l}\text { Countries with per capita GDP } \\
\text { (PPP) }\end{array}$} & \multicolumn{2}{|c|}{ The number of countries with a total fertility rate of } & \multirow{2}{*}{$\begin{array}{c}\text { Total number of } \\
\text { countries }\end{array}$} \\
\cline { 2 - 4 } & less than 1.5 & $1.5-1.8$ & 1.8 and higher & 11 \\
\hline Less than 17,000 dollars & 6 & 3 & 2 & 11 \\
\hline 17,000 dollars and more & - & 7 & 4 & 11 \\
\hline
\end{tabular}

Sources: Author's calculations based on (Demoscope Weekly. Supplementary materials 2018; Maddison 2010).

After the countries that had been part of the USSR, the Soviet military-political bloc and Yugoslavia, previously relatively isolated from the world economy, became the economic periphery and semi-periphery of the developed world, the direct relationship between per capita income and fertility for some time noticeably increased. In 2000, in the aggregate of 38 countries ${ }^{11}$, there was a direct $(r=0.59)$ and statistically significant at $\alpha<0.001$ link between per capita GDP (PPP) and TFR (Figure 4).

${ }^{10}$ Calculations of the author based on (Demoscope Weekly. Supplementary materials 2018; Maddison 2010) in 1990 for the 22 countries mentioned above, in 1950 for the same countries without South Korea.

${ }^{11}$ The totality of the 41 countries listed above, excluding Bosnia and Herzegovina, Serbia and Montenegro. 


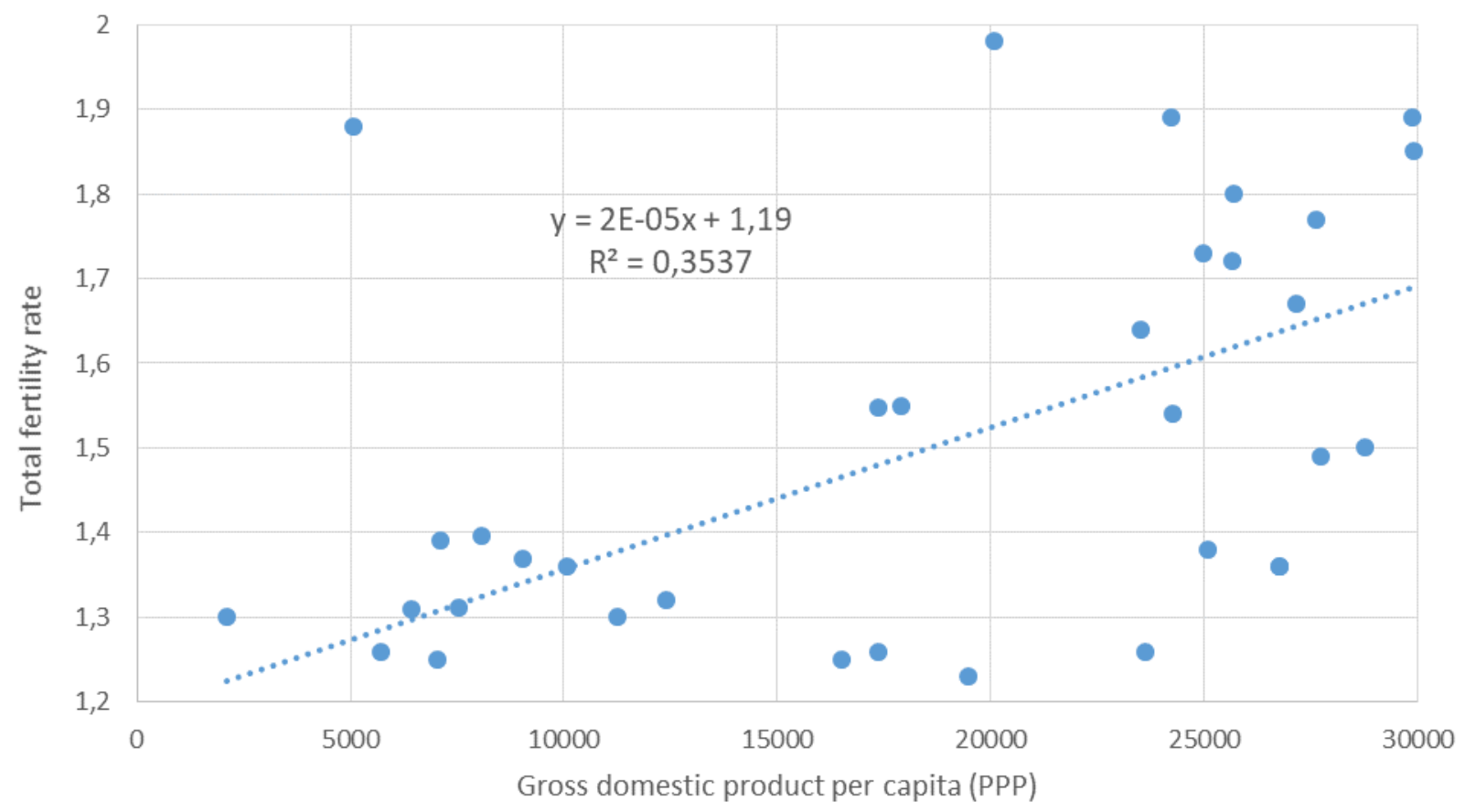

Figure 4. Gross domestic product and total fertility rate in 38 developed countries, 2000

Sources: (Demoscope Weekly. Supplementary materials 2018; UNDP 2002: 149-152).

In 2015, the relationship between gross national income (hereinafter referred to as GNI) per capita and the TFR for the 41 countries in question remained statistically significant at the $1 \%$ level $(r=0.41)$, although not as close as it was one and a half decades earlier. As in 2000, relatively high fertility was possible only for countries that had secured a place in the core of the worldsystem. Being in such a core was, as in 2000, a necessary but insufficient condition for achieving a fertility level close to replacement level (table 2).

Table 2. Distribution of countries in the periphery, semi-periphery and core of the developed world by the total fertility rate in 2000 and $2015, \%$

\begin{tabular}{|c|c|c|c|c|c|c|c|}
\hline \multirow[t]{2}{*}{ Year } & \multirow{2}{*}{$\begin{array}{l}\text { Group of } \\
\text { countries }\end{array}$} & \multirow{2}{*}{$\begin{array}{c}\text { GDP (PPP) per } \\
\text { capita*. } \\
\text { thous. dollars }\end{array}$} & \multirow{2}{*}{$\begin{array}{c}\text { Number } \\
\text { of } \\
\text { countries }\end{array}$} & \multicolumn{4}{|c|}{ Distribution of countries by TFR, $\%$} \\
\hline & & & & $\begin{array}{c}\text { Less than } \\
1.5\end{array}$ & $1.5-1.8$ & $\begin{array}{c}1.8 \text { and } \\
\text { more }\end{array}$ & Total \\
\hline \multirow{3}{*}{2000} & Periphery & Less than 10 & 11 & 90.9 & - & 9.1 & 100 \\
\hline & Semi-periphery & $10-20$ & 9 & 77.8 & 22.2 & - & 100 \\
\hline & Core & 20 and more & 18 & 27.8 & 38.9 & 33.3 & 100 \\
\hline \multirow{3}{*}{2015} & Periphery & Less than 20 & 9 & 33.3 & 66.7 & - & 100 \\
\hline & Semi-periphery & $20-35$ & 16 & 56.3 & 37.5 & 6.3 & 100 \\
\hline & Core & 35 и more & 16 & 12.5 & 56.3 & 31.3 & 100 \\
\hline
\end{tabular}

Note: * - in 2015, gross national income (PPP) per capita.

Sources: Author's calculations based on (Demoscope Weekly. Supplementary materials 2018; UNDP 2002:

149-152; UNDP 2016: 198-201). 
The consequence of the economic and political restructuring of the world, which occurred at the end of the 1980s and start of the 1990s, was the formation of four attractors ${ }^{12}$. The first of these is an institutional trap that "pulls" peripheral countries when they are integrated into the capitalist world-system. The vital needs of young people in peripheral countries in this case are formed on the basis of comparison with their more developed neighbors, and the impossibility of satisfying these needs leads to a decrease in fertility. An additional factor in this decline is the emigration of a significant part of the population of peripheral countries to the countries of the semi-periphery and the core of the world-system. Such a situation is observed, for example, in Moldova and Ukraine.

The second attractor is another type of institutional trap. A low standard of living is no longer in this case a factor in the decline in fertility, since its main cause is the contradiction between the rapidly changing structure of life outside the family and the more inert norms of family relations. This trap attracts the most developed countries of the world (examples are Germany and Japan). The third attractor attracts semi-peripheral countries, combining in some proportions the properties of the first and second attractors.

The fourth attractor also has magnetic power, but unlike the first three, it is not a trap, but an ideal. It is based on the idea that a generous demographic or family policy that helps women combine parental and maternal roles, together with more evenly divided household responsibilities between spouses than in a conservative family, can provide a birth rate that ensures simple replacement of generations. The "material basis" of this ideal, which makes it possible not to consider it a purely speculative utopia, is the current demographic situation in the Nordic countries and France, where fertility has come closer to reaching the replacement level than in other developed European countries.

The relatively high birth rate in France, for example, has been greatly facilitated by the timely transformation of family policy (Toulemon, Pailhé, Rossier 2008). This policy, originally focused on a single-breadwinner family model, was subsequently transformed in such a way as to facilitate women's combination of maternal and professional roles. The development of the situation in the Nordic countries, according to a number of authors, gives hope that the "second half of the gender revolution", expressed in the broader involvement of men in household chores, will lead to an increase in fertility (Goldscheider, Bernhardt, Lappegârd 2015: 229).

These attractors, which make up a system with four centers of gravity, have determined and will presumably continue to determine the dynamics of fertility in the developed world in the near future. In the 1990s, the first of these attractors "pulled" into trap countries, transforming their socio-economic system; Russia was one of them. With the improvement of the economic situation, most of these countries managed to get out of the gravitational field of this attractor, while, among former Soviet republics, Ukraine and Moldova remain closest to it.

Having escaped from the trap of the first attractor, the countries that underwent a transformation of their socio-economic and political structure at the end of the last century have nonetheless not reached the fourth. The demographic goal of most governments in countries

${ }^{12}$ The expediency of borrowing this concept from the synergetics is, in our case, due to the fact that it defines an object that attracts other objects to itself and is their limiting state. 
belonging to the periphery and semi-periphery of the developed world is to achieve the fertility characteristic of such core-world countries as France or the USA. Realization of this goal is hampered, however, by a lack of sufficient resources due to their peripheral or semi-peripheral position. Moreover, the risk of returning to the former, extremely low birth rates remains quite real. The governments of this group of countries more often see a way out of the current situation in the redistribution of available resources in favour of demographic or family policy.

The demographic policy of modern Russia is an example of such a strategy, but today it is no longer unprecedented - it has, irrespective of geopolitical orientation, been adopted by other countries. The most recent examples include Hungary and Poland. In 2016, the new Polish government announced the launch of the "Family 500+" program, previously promised to voters. This program provides benefits in the amount of 500 PLN (hence the " $500+$ " in the title) to families with two or more children (Kulczyk 2016). Hungary announced that, starting from 2018, at the birth of a second child families will have half their student loans forgiven, and at the birth of a third - the whole loan, and that new tax breaks will be introduced and support will be given to families who buy housing on credit $^{13}$.

The problems of countries that have fallen into the gravitational field of the second and third attractors (typical examples are Germany and Spain, respectively) are not only or not so much in the lack of resources, but in the inertia of informal and formal institutions formed by the family doctrines that have prevailed for many years. The fourth ("ideal") attractor has been most closely approached by countries with a high standard of living. In the twenty-first century, if we are talking about the developed world, it has been possible to achieve a TFR value close to the replacement level only in countries with very high per capita income, which include France, Sweden, Ireland, the USA and, with some reservations, a number of other countries.

\section{CONCLUDING REMARKS}

A number of methodologists (Tilly, Goodin 2006) share research strategies aimed at finding common laws and mechanisms. The latter can be defined as chains linking the causes of events, the events themselves and their results. According to the expression of O. Yu. Malinova, "the mechanism is less than theory, but more than description, because it can serve as a model for explaining other cases" (Malinova 2013: 14). The study of mechanisms is closely related to diachronic or, as they are also called, "genetic" explanations, the purpose of which is to show how subsequent events grow from previous ones.

The analysis carried out in this paper gives grounds to talk about several mechanisms linking political and demographic history. One such mechanism consists of pronatalist demographic policies, often, though not always, arising as a response to an external threat. The chain of cause-effect relationships is sometimes very long. Thus, the Franco-Prussian war of 1870-1871, which had a great influence on the French political class, led to the emergence of

\footnotetext{
${ }^{13}$ URL: http://abouthungary.hu/blog/hungary-names-2018-the-year-of-the-family/ (reference date 04.08.2018). 
French pronatalism, which in turn played a significant role in shaping demographic, and then modern family policy in France.

Another mechanism links integration into the capitalist world-system of states that were previously isolated from it with a decrease in their birth rate.

With all the obvious differences between countries that have moved from more or less pronounced autarchy to close integration into the capitalist world-system, inclusion in it in all cases was possible only as part of the semi-periphery or periphery. In this case, the mediating links between integration and declining fertility were new standards of quality of life and a lowering of the barrier functions of borders. The contradiction between needs and opportunities was resolved either by refusing to give birth to second and subsequent children, or by emigration of the population of reproductive age to the countries of the core, which again reduced the birth rate.

Although the period of transformational shock is now over, the nature of the effect of migration on fertility is still closely related to the position of countries on the center-peripheral scale. The countries of the core of the world-system are the most attractive for immigrants, while the peripheral countries become migratory donors and lose their reproductive contingents. In this respect, semi-peripheral countries occupy an intermediate and unstable position. A striking example is Spain, in which the economic and immigration boom at the beginning of the $21 \mathrm{st}$ century was replaced after the beginning of the 2008-2009 crisis by an outflow of qualified youth to the countries of the European core. The low birth rate observed on the periphery and semiperiphery of the developed world is thus the result of structural constraints built into the worldsystem, making relatively high fertility a privilege available only to the richest countries. The question of whether these limitations can be overcome by redistributing the resources of the semi-peripheral and peripheral countries of the developed world in favour of family and demographic policy remains open.

\section{REFERENCES}

Andersson G., J. A.-Z. Hoem, Duvander (2005). Social differentials in speed-premium effects in childbearing in Sweden // MPIDR working paper 2005-027. URL: www.demogr.mpg.de/papers/working/wp-2005-027.pdf (accessed: 05.05.2018).

De Gaulle Ch. (2004). Voennye memuary [War memoirs]. T.3. [Vol.3]. Spasenie 1944-1946 [Salvation 1944-1946]. Moscow: AST, Astrel', Tranzitkniga. 799 p.

Demoscope Weekly. Prilozenie. [Demoscope Weekly Supplementary materials] (2018).

Koeffitsient summarnoy rozhdaemosti [Total fertility rate].URL: http://www.demoscope.ru/weekly/app/app4007.php (accessed: 14.04.2018).

Family Database (2018). OECD. URL: http://www.oecd.org/els/family/database.htm\#TOP (accessed: 30.04.2018).

Frejka T. (1980). Fertility trends and policies: Czechoslovakia in the 1970s // Population and Development Review: 6(1) 65-93.

Goldscheider F., E. Bernhardt, T. Lappegârd (2015). The gender revolution: a framework for understanding changing family and demographic behavior // Population and Development Review. 41 (2): 207-239. 
Kulczyk M. (2016). Family rights and family policy in Poland. European Center for Law and Justice. URL: http://media.aclj.org/pdf/Marcin-KULCZYK-Family-rights-and-family-policyin-Poland.pdf (accessed: 28.04.2018).

Lesthaeghe R., L. Neidert (2009). Presidential elections and the spatial pattern of the American second demographic transition // Population and Development Review. 35(2): 391-400.

LFS (2018). LFS by age and sex - indicators. OECD. URL: https://stats.oecd.org/Index.aspx?DataSetCode=LFS_SEXAGE_I_R\# (accessed: 30.04.2018).

Maddison A. (2010). Historical Statistics of the World Economy URL: www.ggdc.net/maddison/historical_statistics/horizontal-file_02-2010.xls (accessed: 28.04.2018).

Malinova O.Yu. (2013). Konstruirovanie smyslov: issledovanie simvolicheskoy politiki v sovremennoy Rossii [Constructing Meanings: Study of Symbolic Politics in Modern Russia] Moscow: RAN INION. 421 p.

Meil Landwerlin G. (1995). Presente y futuro de la política familiar en España // Reis. Revista española de investigaciones sociológicas. 1(70): 67-90.

Morago Garcia M. (2008). Notas sobre la situacion jurídica De la mujer en el franquismo // Feminismo/s. 12: 229-252.

Niehus M. (1995). French and German family policy 1945-60 // Contemporary European History. 4(3): 293-313.

Nielfa Cristóbal G., ed. (2003). Mujeres y hombres en la España franquista: sociedad, economía, política, cultura. Madrid. 303p.

Rindfuss R., K. Guzzo, S. Morgan (2003). The changing institutional context of low fertility // Population Research and Policy Review. 22 (5/6): 411-438.

Tilly Ch., R. Goodin (2006). It depends // The Oxford Handbook of Contextual political analysis / Ch.Tilly, R.Goodin, eds. Oxford: Oxford University Press: 3-34.

Toulemon L., A. Pailhé, C. Rossier (2008). France: High and stable fertility // Demographic Research. 19: 503-556. URL: http://www.demographic-research.org/Volumes/Vol19/16 (accessed: 05.05.2018).

UNDP (2002). Human Development Report 2002. Deepening democracy in a fragmented world. NY. 277 p.

UNDP (2016). Human Development Report 2016. Human Development for Everyone. NY. $271 \mathrm{p}$.

Van de Kaa D. (1996). Anchored narratives. The story and findings of half a century of research into the determinants of fertility // Population Studies. 50(3): 389-432. 